\title{
PRODUCTION AND CONSUMPTION OF FUELWOOD AS ENERGY RESOURCE: CASE OF LATVIA
}

\author{
Gunita Mazure, Gunta Grinberga-Zalite \\ Latvia University of Agriculture \\ gunita.mazure@1lu.lv,gunta.grinberga@1lu.lv
}

\begin{abstract}
In Latvia, renewable energy occupies more than $30 \%$ in the primary energy balance, since wood, including firewood, wood chips, wood waste, briquettes, pellets, and hydro resources are two most frequently used forms of renewable energy. Fuelwood is the most common form of renewable energy resources, and its share in total energy consumption has increased from $23.4 \%$ in 2010 to ca. $28.2 \%$ in 2015 . The research aim is to analyse the production, consumption and trade of fuelwood based on the forecasts for fuelwood consumption by 2020. Various forecasts show the maximum demand for fuelwood in 2019 amounting to 6.8 million $\mathrm{m}^{3}$ with a minor decline in the following year to 6.3 million $\mathrm{m}^{3}$; however, the present research demonstrates that the fuelwood consumption decreases from 2015 and following the declining trend, the demand for fuelwood could be even smaller than forecasted. The research reflects that total fuelwood consumption in 2014 has increased by $4.65 \%$ compared with 2013 due to the increase in the share of fuelwood consumption both by households and transformation sector generating heat and electricity, while in 2015 it has dropped by $8.1 \%$. The main consumers of fuelwood are households, mostly using wood (54\% on average). In 2014, consumption of fuelwood share of households was $44.6 \%$, while in 2015 it was $38.2 \%$. The major export markets for Latvian timber products are the UK, Germany, Sweden and Estonia. In the first half of 2015, fuelwood amounted for $13 \%$ of forest industry exports. However, the structure of timber product exports has undergone considerable changes: before the 2008 crisis particular exports were related to construction products export like timber, though during the crisis period, the share of fuelwood exports increased with the decrease of the demand and production of timber. This is mainly due to the improvement and growth of timber enterprise technological capabilities and production capacities. The large share of wood and its products exports contributed to the economic recovery in the post-crisis period.
\end{abstract}

Keywords: fuelwood, renewable energy, fuelwood production, fuelwood consumption.

\section{Introduction}

The European Union is striving to become a global leader in the use of renewable energy due to its ambitious policies and advanced businesses. In 2014, renewable energy sources powered almost $15.5 \%$ of the EU energy sector; thus supplying 78 million Europeans with energy [1]. The EU's Renewable Energy Directive has set a target to consume $20 \%$ of final energy from renewable sources by 2020. Therefore, the EU Member States have undertaken their own commitments to achieve the national renewable targets, which range between $10 \%$ in Malta and $49 \%$ in Sweden [2]. In 2015, approximately $27 \%$ of the EU's electricity was generated by renewable energy sources, and it is forecasted to achieve $50 \%$ by 2030. Consistent with Annex I(A) of the Directive 2009/28/EC, Latvia has advanced a comprehensive objective to increase the share of energy produced from renewables in the gross final energy consumption from $32.6 \%$ in 2005 to $40 \%$ in 2020 [3].

Romeo and Santos have admitted that renewable energies are the only sources that would have a durable future in Europe, since the generation of renewable energy may help considerably reduce the $\mathrm{CO}_{2}$ emissions [4]. Renewable energy resources are potentially significant as they can outpace the world's energy demand; thus, these energy resources will occupy an essential share in the future global energy portfolio [5].

Several researchers have recognised that Latvia's energy consumption is provided from local energy resources and the import of primary resources from Russia, the CIS countries, Estonia, Lithuania and other EU Member States. Presently, oil products, natural gas and fuelwood constituting approximately equal proportions are the three types of energy resources, which dominate in the delivery of Latvia's primary resources [6]. Similar conclusions are made by Melece and Krievina (2015) stating that "the fuelwood is the main source of biomass in Latvia and its share, especially of wood pellets, is growing in renewable energy". At the same time, the researchers indicate on the increase of the fuelwood production indicating to limited consumption due to fuelwood, particularly wood pellets, exports [7]. In addition, the researchers have identified a contradiction between the practice applied in Latvia and other EU Member States having high potential of wood resources, for example, Finland and Sweden [7]. 
The present research is aimed to analyse the production, consumption and trade of fuelwood based on the forecasts for fuelwood consumption by 2020. The following research tasks are advanced to achieve the research aim: 1) to study the basic figures for the fuelwood output and consumption; and 2) to provide an insight into the forecasts related with the fuelwood production and consumption. According to the definitions of the Joint Forest Sector Questionnaire, fuelwood is roundwood "used as fuel for cooking, heating or power production". In general, fuelwood includes "wood harvested from main stems, branches and other parts of trees and wood that is used for charcoal production. It also includes wood chips to be used for fuel that are made directly from roundwood and it excludes wood charcoal" [8].

\section{Materials and methods}

The information of the Central Statistical Bureau of Latvia, the Ministry of Agriculture, regulatory enactments of the European Commission and the Republic of Latvia, scientific publications of foreign and national researchers, and other materials were used for the purpose of the study. The research is based on the appropriately selected methods: monographic descriptive method, methods of analysis and synthesis, data grouping, logical and constructional methods.

The research authors have applied the following recalculation coefficients to compute comparable statistical indicators: 1 solid $\mathrm{m}^{3}=0.4 \mathrm{~m}^{3}, 1$ solid $\mathrm{m}^{3}=0.69 \mathrm{t}, 1$ loose $\mathrm{m}^{3}=0.28 \mathrm{t}$ [9].

\section{Results and discussion}

The forest resources themselves and their use as energy resource have historically been a driving force for the socio-economic development of Latvia. In general, forestry has been one of the basic sources of employment and income generation for the whole country. Therefore, timber and other wood products may be considered as one of the most significant renewable natural resources in Latvia. The application of renewable resources greatly depend on the technologies and substitution of conventional forestry products like firewood and wood chips with the products that require less production, transportation and storage costs [10]. Figure 1 shows that the generation of energy wood is possible within the entire wood processing stages, i.e. from forestry scraps to the secondary utilisation of timber as fuelwood.

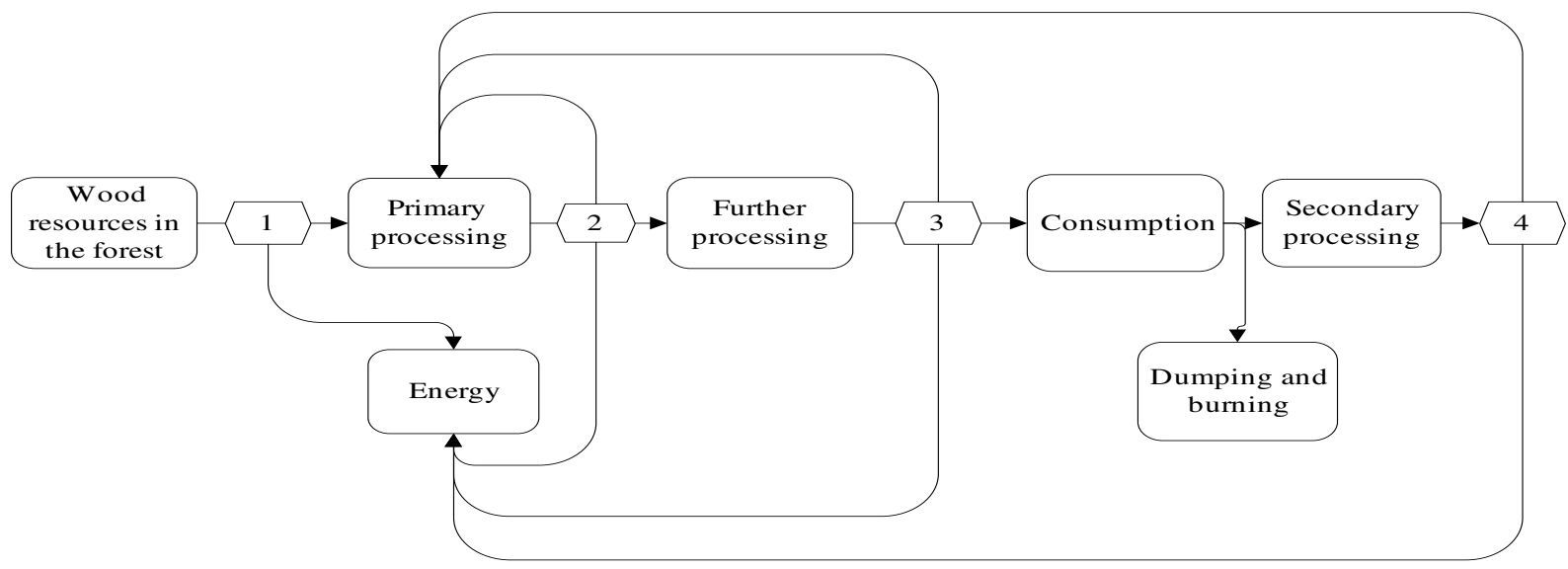

Fig. 1. Possibilities for utilisation of wood resources [11]

Wood utilisation starts from wood resources in the forest following through several stages of processing, i.e. primary, further and secondary ones. An effective utilisation of raw materials is ensured by an efficient use of all forestry by-products and scraps [10]. Fuelwood may be obtained in almost all wood-processing cycles as it includes firewood, wood wastes, wood chips, wood briquettes and pelleted wood - obtaining of firewood from wood resources and processing into energy source (Stage 1); after that wood products may be transported for further processing (Stage 2); then used for consumption (waste, chips) or after the secondary processing used as energy source (Stages 3 and 4).

In Latvia, renewable energy occupies more than $30 \%$ in the primary energy balance, since wood, including firewood, wood chips, wood waste, briquettes, pellets, and hydro resources are two most frequently used forms of renewable energy [12]. In the first half of 2015, fuelwood amounted for $13 \%$ 
of forest industry exports. However, the structure of timber product exports has undergone considerable changes: before the 2008 crisis particular exports were related to construction products export like timber, though during the crisis period, the share of fuelwood exports increased with the decrease of the demand and production of timber. This is mainly due to the improvement and growth of timber enterprise technological capabilities and production capacities. The large share of wood and its products exports contributed to the economic recovery in the post-crisis period [12]. Both historically and nowadays, the energy sector is the largest wood consumer due to the necessity to ensure heat for production and population leading to the analysis of the fuelwood production and consumption volumes (Fig. 2).

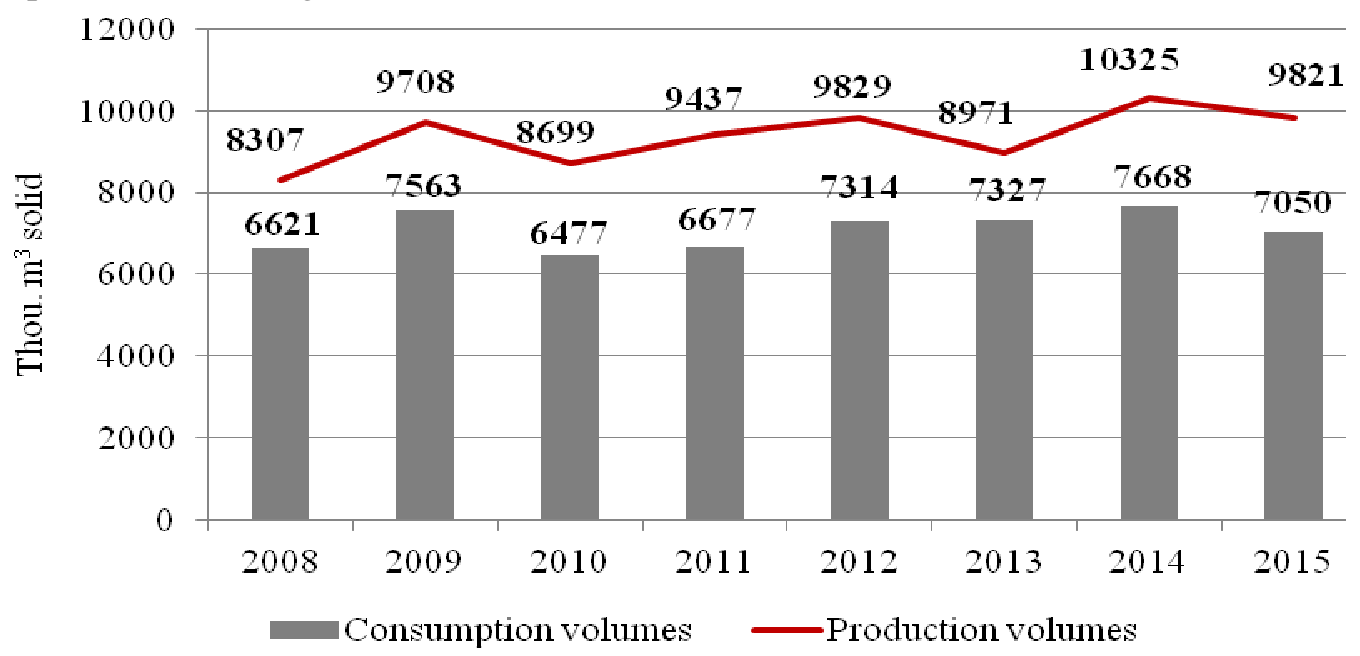

Fig. 2. Fuelwood production and consumption volumes in Latvia for the period 2008-2015, thou.m ${ }^{3}$ solid [13]

In Latvia, the annually available traditional fuelwood volumes (firewood, wood briquettes, wood chips, and other wood waste) fluctuate around 9.4 million $\mathrm{m}^{3}$. The highest peak in fuelwood production was reached in 2014, when it increased by 1.35 million $\mathrm{m}^{3}$ or $15.1 \%$ compared with the previous year; thus, amounting to 10.33 million $\mathrm{m}^{3}$. The largest volumes of fuelwood consumption are also observed in 2014 , i.e. 7.67 million $\mathrm{m}^{3}$. Traditionally, the annual fuelwood consumption fluctuates around 7.1 million $\mathrm{m}^{3}$, the rest of fuelwood volume is exported. In 2012, the fuelwood consumption increased by 0.64 million $\mathrm{m}^{3}$ or $9.54 \%$ compared with 2011 . The increase relates with a number of fuelwood use projects, some of the major projects being in Ventspils, Liepaja and Jelgava city district heating systems which were reoriented of gas and fuel oil to fuelwood chips as well as the initiation of a new chip manufacturing project and processing plant for modernisation of the energy sector. Despite such an impressive project implementation, Latvia still has large stocks of fuelwood for domestic energy. The growing domestic consumption partially reduced the fuelwood volume available for exports; nevertheless, the fuelwood exports maintained a significant volume (Fig. 3).

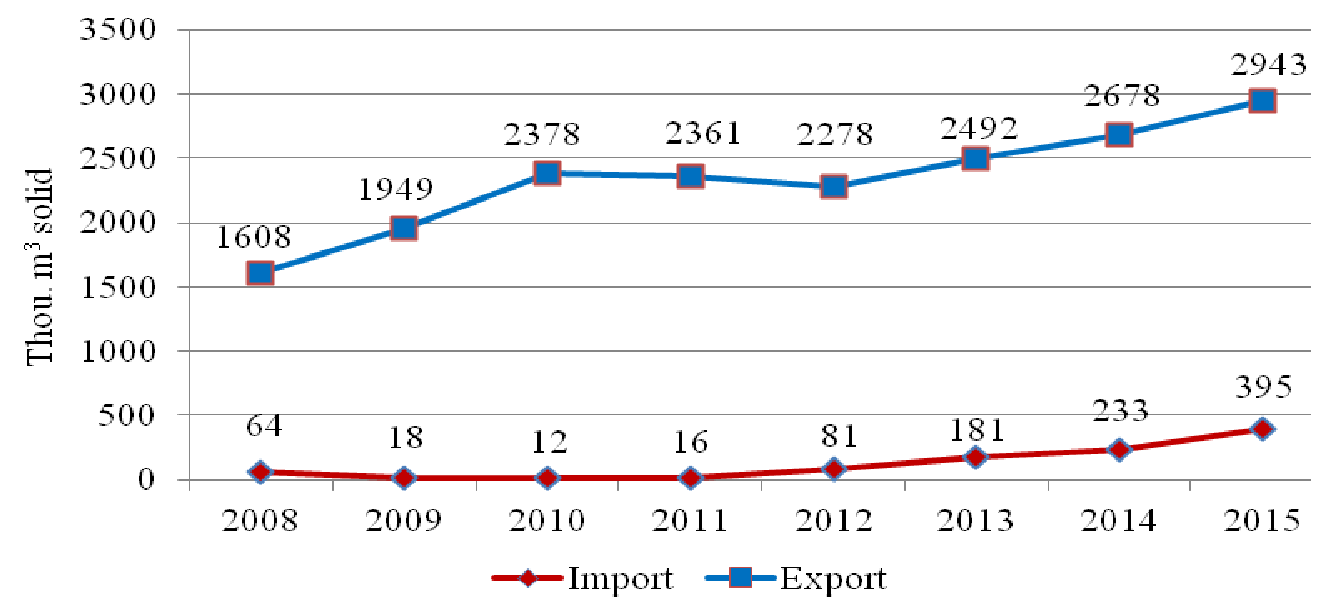

Fig. 3. Import and export volumes of fuelwood in Latvia for the period 2008-2015, thou $\cdot \mathrm{m}^{3} \mathrm{solid}$ [13] 
In 2015, Latvia exported 2.9 million $\mathrm{m}^{3}$ of fuelwood, where pelleted wood and wood chips accounted for $52.77 \%$ and $33.71 \%$ respectively. In addition, exports include wood wastes, firewood and wood briquettes. This volume of exports is the highest one during the analysed period and it may relate with a sharp decline in the fuelwood consumption (decrease by $8.06 \%$ compared with 2014). At the same time, imports have grown by $69.5 \%$ compared with the previous year. The major export markets for Latvian timber products are the UK (in 2015 - 19.6\% of the total timber export, excluding furniture), Germany (10.6\%), Sweden (9.4\%) and Estonia (6.3\%). In the first half of 2015, fuelwood amounted for $13 \%$ of forest industry exports [13].

Wood chips and sawdust are the major imported fuelwood products from Lithuania, Estonia, Belarus and Russia. This relates with the comparatively low share of wood chips and wood briquettes in total volumes of fuelwood production (Fig. 4).

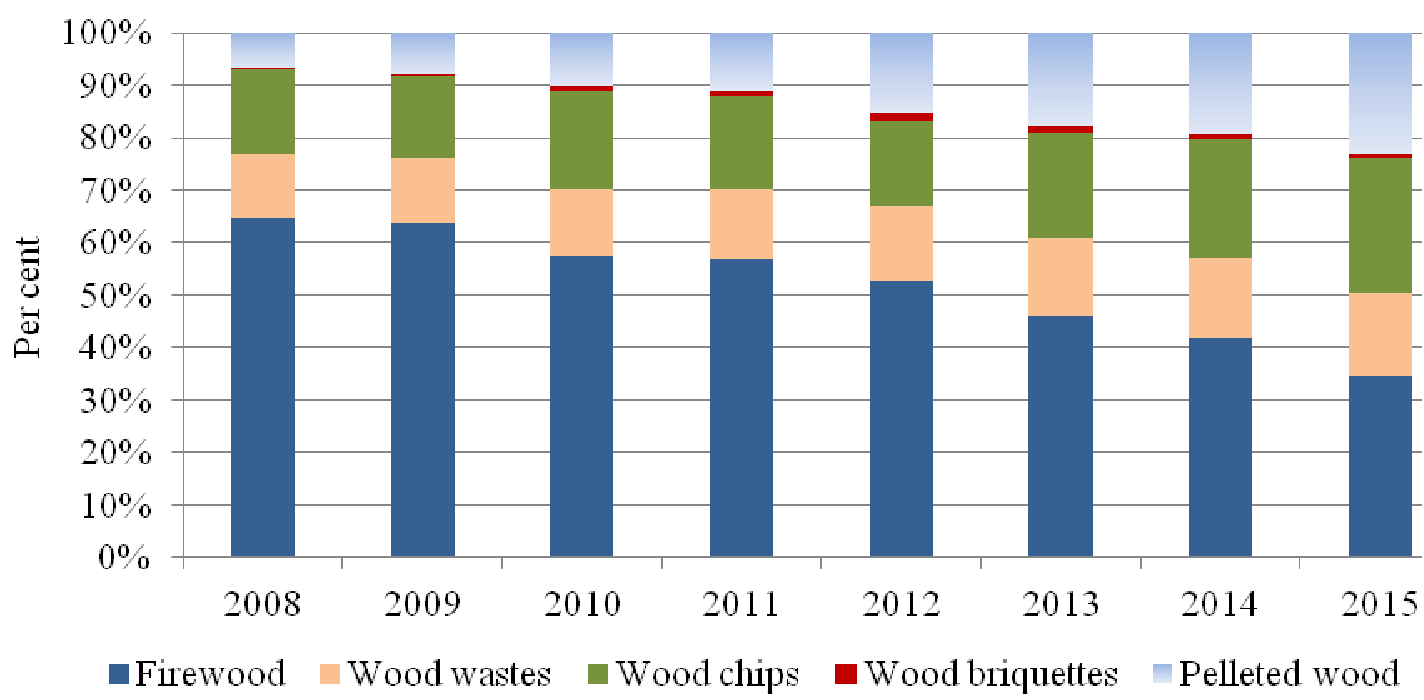

Fig. 4. Fuelwood production by types of fuelwood in Latvia for the period 2008-2015, \% [13]

The analysis of fuelwood production by its types shows that firewood occupies the largest share in total fuelwood production; however, it has decreased from $65 \%$ to $35 \%$ during the analysed period. The increase in the share of wood chips (from $16 \%$ to $26 \%$ ) and pelleted wood (from $6.6 \%$ to $23 \%$ ) mainly explain the change in the structure of fuelwood production.

The changes in production and consequently in export and import volumes greatly coincide with the changes in consumption of energy resources including both renewable and non-renewable resources (Table 1).

Table 1

Gross consumption of energy resources in Latvia in the period 2010-2015, PJ [14]

\begin{tabular}{|c|c|c|c|c|c|c|}
\hline Resource & $\mathbf{2 0 1 0}$ & $\mathbf{2 0 1 1}$ & $\mathbf{2 0 1 2}$ & $\mathbf{2 0 1 3}$ & $\mathbf{2 0 1 4}$ & $\mathbf{2 0 1 5}$ \\
\hline Oil products & 64.6 & 59.5 & 58.4 & 59.3 & 59.7 & 62.6 \\
\hline Natural gas & 61.3 & 54.0 & 50.8 & 50.3 & 45.4 & 46.1 \\
\hline Fuelwood & 45.6 & 46.9 & 52.5 & 53.1 & 55.9 & 52.6 \\
\hline Electric energy & 16.0 & 15.1 & 19.8 & 15.8 & 16.0 & 13.8 \\
\hline Coal & 4.4 & 4.5 & 3.6 & 3.0 & 2.5 & 2.0 \\
\hline Other & 2.9 & 4.2 & 5.4 & 5.6 & 6.7 & 7.9 \\
\hline Total & 194.8 & 184.2 & 190.5 & 187.1 & 186.2 & 185.0 \\
\hline $\begin{array}{c}\text { Share of } \\
\text { fuelwood, \% }\end{array}$ & 23.41 & 25.46 & 27.56 & 28.38 & 30.02 & 28.43 \\
\hline
\end{tabular}

Over the period 2010-2015, the gross consumption of fuelwood has grown by $15.35 \%$, thus amounting to 52.6 PJ. In 2015, the share of fuelwood in the total energy consumption was $28.43 \%$, i.e. by 1.59 percentage points less compared with the previous year, when it reached the maximum value $-30.02 \%$. According to the Central Statistical Bureau, in 2015, Latvia's exports of fuelwood 
reached 33.7 PJ, which accounted for $11.1 \%$ more than in 2014 [14]. This means that the amount of produced wood pellets and wood chips increased by $14.1 \%$ and $8.4 \%$ respectively. In 2015, Latvia's exports of wood pellets accounted for $28.0 \mathrm{PJ}$ or $20.4 \%$ more than in 2014. Nevertheless, oil products occupy the largest share of consumed energy resources in Latvia, only then followed by fuelwood and natural gas.

The household sector is still the major fuelwood consumer; though, its share has decreased by 29.5 percentage points during the period of eight years, thus, constituting $38.2 \%$ of the gross consumption of fuelwood in 2015. The consumption of fuelwood in the industry and construction sector has increased 2.74 times compared with the base year 2008; thus, accounting for $29.3 \%$ of the gross consumption of fuelwood in this sector in the latest year of analysis, i.e., the year 2015 (Fig. 5).

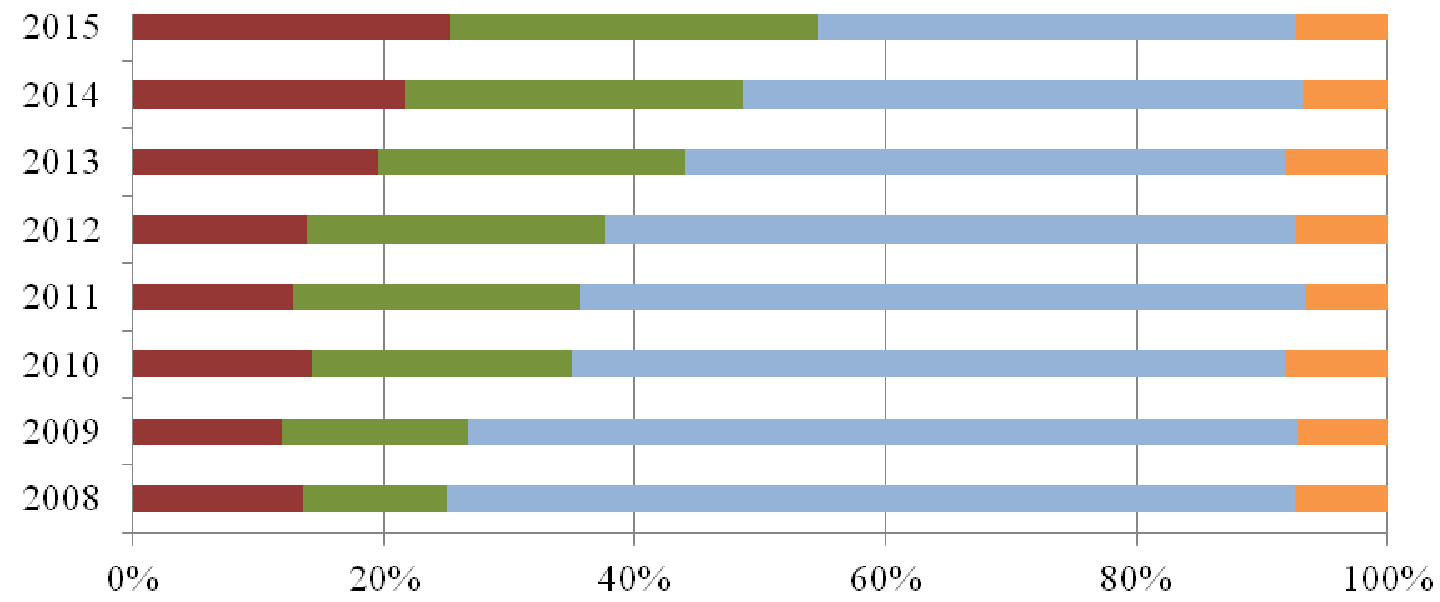

Transformation sector Industry and construction ${ }^{\text {Households }}$ Other sectors

\section{Fig. 5. Fuelwood consumption by types of sectors in Latvia for the period 2008-2015, \% [13]}

The growth in the share of industry and construction is logic, as fuelwood is the most competitive energy resources in heat production sector.

Various forecasts show the maximum demand for fuelwood in 2019 amounting to 6.8 million $\mathrm{m}^{3}$ with a minor decline in the following year to 6.3 million $\mathrm{m}^{3}$ [15]. The present research demonstrates that the fuelwood consumption decreases from 2015 and following the declining trend, the demand for fuelwood could be even smaller than forecasted. However, the situation of fuelwood market may change due to different factors, the primary factor being the expansion of fuelwood use in the industrial sector.

\section{Conclusions}

1. In Latvia, renewable energy occupies more than $30 \%$ in the primary energy balance, since wood, including firewood, wood chips, wood waste, briquettes, pellets, and hydro resources are two most frequently used forms of renewable energy.

2. The annually available traditional fuelwood volumes fluctuate around 9.4 million $\mathrm{m}^{3}$, reaching the highest peak in fuelwood production in 2014, while the annual fuelwood consumption fluctuates around 7.1 million $\mathrm{m}^{3}$, the rest of fuelwood volume is exported. The growing domestic consumption partially reduced the fuelwood volume available for exports; nevertheless, the fuelwood exports maintained an impressive volume.

3. The gross consumption of fuelwood has grown by $15.35 \%$, thus, amounting to $52.6 \mathrm{PJ}$ over the period 2010-2015, namely, in 2015, the share of fuelwood in the total energy consumption was $28.43 \%$, i.e. by 1.59 percentage points less compared with the previous year, when it reached the maximum value $-30.02 \%$.

4. The household sector is still the major fuelwood consumer; though, its share has decreased by 29.5 percentage points during the period of eight years; thus, constituting $38.2 \%$ of the gross consumption of fuelwood in 2015. 


\section{References}

1. The European Union leading in renewable. [online] [10.03.2017]. Available at: http://ec.europa.eu/energy/sites/ener/files/documents/cop21-brochure-web.pdf.

2. Renewable energy directive. [online] [10.03.2017]. Available at: http://eur-lex.europa.eu/legalcontent/EN/ALL/?uri=CELEX:32009L0028.

3. Information report of the Republic of Latvia - National renewable energy action plan for implementing Directive 2009/28/EC of the European Parliament and of the Council of 23 April 2009 on the promotion of the use of energy from renewable sources and amending and subsequently repealing Directives 2001/77/EC and 2003/30/EC by 2020. [online] [10.03.2017]. Available at: https://ec.europa.eu/energy/node/71.

4. Romero SR., Santos AC. Gil MAC. EU plans for renewable energy. An application to the Spanish case. Renewable Energy. Volume 43, July 2012, pp. 322-330. [online] [10.03.2017]. Available at: http://www.sciencedirect.com/science/article/pii/S0960148111006355.

5. Ellabban O., Abu-Rub H., Blaabjerg F. Renewable energy resources: Current status, future prospects and their enabling technology. Renewable and sustainable energy reviews. Volume 39, November 2014, pp. 748-764. [online] [10.03.2017]. Available at: http://www.sciencedirect.com/science/article/pii/S1364032114005656.

6. Shipkovs P., Pelite U., Kashkarova G. et al. Policy and strategy aspects for renewable energy sources use in Latvia. Policy Issues. World Renewable Energy Congress, 2011 pp. 2438-2445. [online] [12.03.2017]. Available at: http://www.ep.liu.se/ecp/057/vol10/021/ecp57vol10_021.pdf.

7. Melece L., Krievina A. Issues of solid wood biomass development for bioenergy in Latvia. Proceedings of the international scientific conference "Engineering for Rural Development 2015". [online] [15.03.2017]. Available at:

http://tf.llu.lv/conference/proceedings2015/Papers/079_Melece.pdf.

8. Joint forest sector questionnaire. Definitions, UN-ECE/FAO/Eurostat/ITTO. [online] [20.02.2017]. Available at: https://circabc.europa.eu/sd/a/a9d1d4df-96ac-4053-bcd23105dc6ba6cd/Definitions_EN_2012.pdf.

9. Noradijumi veidlapas "Parskats par energetisko resursu iegadi un izlietosanu (2-EK) aizpildisanai". (Instructions for the filling in the form "Survey on acquisition and use of energy resources"). Cabinet Regulations No 922 of 06.11.2006. [online] [10.01.2017]. Available at: http://www.csb.gov.lv/sites/default/files/instrukcijas/2-ek_n10121043.pdf. (in Latvian).

10. Bite L., Mazure G., Makovskis K. Possibilities to use Latvia wood resources for heat energy production. Proceedings of the international scientific conference "Economic Science for Rural Development' 2011" No 25: Resources and education; Resources and sustainable consumption, Jelgava: LLU, pp. 38-47.

11. Domkins A., Bumanis, K. A European wood processing strategy. Country reports / COST E44/. Edited by Ghent University /Input Wood Processing Strategy. Helsinki, 2008, pp. 183-196.

12. Meza nozare Latvijas 25 neatkaribas gados. (Forest sector in 25 years of Latvia's independence). [online] [10.03.2017]. Available at:

https://www.zm.gov.lv/public/ck/files/Meza_nozare_25_\%20(1).pdf. (in Latvian).

13. Consumption of renewable energy resources in 2015. [online] [18.03.2017]. Available at: http://www.csb.gov.lv/en/notikumi/consumption-renewable-energy-resources-2015-44050.html.

14. Latvijas energobilance 2015. gada. (Energy balance of Latvia in 2015). [online] [10.03.2017]. Available at: http://www.csb.gov.lv/statistikas-temas/metodologija/energobilance-37149.html. (in Latvian).

15. Krasavcevs I., Lise S., Stepina A. Koksnes biomasas izmantosanas energijas ieguve monitorings (Monitoring of the use of wood biomass for energy production). Petijums, 2014. [ online] [10.03.2017]. Available at:

https://www.zm.gov.lv/public/ck/files/ZM/mezhi/MAF/Koksnes \%20biomasas \%20izmantosana $\% 20$ energija \%20ieguve \%20monitorings_MEKA.pdf. (in Latvian). 